\title{
EL GRAN PROFETA ELISEO, UNA COMEDIA INÉDITA DE ANDRÉS GONZÁLEZ DE BARCIA
}

\author{
Elisa Domínguez de Paz \\ Universidad de Valladolid
}

\section{Resumen}

El gran profeta Eliseo de Andrés González-Barcia es una obra inédita y no tocada por la crítica. No se conserva edición alguna y no tenemos constancia de su representación. Es una comedia de tema bíblico-hagiográfico en la que se mezcla lo religioso con lo profano, lo amoroso con lo doctrinal. La música cumple una finalidad no solo estética, sino también ideológica y dramática. Asimismo, la escenografía conjuga los valores doctrinales y espectaculares, pero sin vulnerar el espíritu religioso del texto, mientras que la tramoya y los «efectos especiales» cumplen la misión de realzarlo.

Palabras clave: El gran profeta Eliseo, Andrés González Barcia, inédita, bíblico, hagiográfico.

\section{THE GREAT PROPHET ELISEUS, AN UNPUBLISHED COMEDY PLAY BY ANDRÉS GONZÁLEZ DE BARCIA}

\begin{abstract}
The Great Prophet Eliseus by Andrés González-Barcia is an unpublished play that has not been the object of any review so far. We do not keep any edition of it and we have no record of its performance. It is a biblical-hagiographic comedy that mixes the religious with the profane, light love with sound doctrine. The music fulfills a purpose not only aesthetic, but also ideological and dramatic. Likewise, the scenography combines both the doctrinal and performance values, but without violating the religious spirit of the text, while the stage and the «special effects» fulfill the mission of enhancing it.

Keywords: The Great Prophet Eliseus, Andrés González-Barcia, unpublished, biblical, hagiographic.
\end{abstract}

Fecha de recepción: 28 de febrero de 2019

Fecha de aceptación: 13 de mayo de 2019 
El principal objetivo de este trabajo es estudiar la comedia El gran profeta Eliseo de Andrés González Barcia (1673-1743), inédita y no tocada por la crítica, pues no hay estudios al respecto en la bibliografía antigua y moderna. En esta obra se entrecruza el argumento bíblico-hagiográfico con la subtrama amorosa con el fin de construir un espectáculo edificante y doctrinal, pero sin anular la vertiente festiva y de entretenimiento que toda comedia barroca debía tener.

\section{El AUTOR}

Andrés González-Barcia Carballido y Zúñiga es el nombre completo de este político y escritor que vivió a caballo entre los siglos XVII y XVIII. Nace en Galicia en 1643, aunque se desconoce la localidad exacta y muere en Madrid el 4 de octubre de 1743 (Aparisi, 2013: 227; Madroñal, 2010: 345), pero la mayoría de estudiosos opina que este escritor es madrileño (Aguilar Piñal, 1981-2002; Andrés, 1987: 811-831; Álvarez Baena, 1791: 106-110; Barrera, 1860: 177; Fayard, 1982: 460-463; Sánchez Mariana, 1993: 65; Urzáiz, 2002: 149). González Barcia participó de la vida política y cultural del Madrid de estos siglos siendo una persona conocida y reconocida por sus contemporáneos. Trabajó como abogado y entró al servicio del rey Felipe V en 1706 ocupando el cargo de Superintendente del Real Aposento de Corte. Asimismo desempeñó otros puestos como el de Juez privativo de Rentas Reales y Millones y posteriormente el de Gobernador de la Sala de Alcaldes de Casa y Corte, hasta convertirse en 1729 en miembro del Supremo Consejo y Cámara de Castilla y asesor de Guerra y Gobernador de la Sala de Alcaldes y Cortes. Fue académico fundador de la Real Academia Española en la que permaneció durante treinta años siendo el primer ocupante del sillón con la letra $\mathrm{D}^{1}$. También participó en las tertulias celebradas por el Marqués de Villena, desde 1711, en su palacio de las Descalzas Reales de Madrid. Como bibliófilo y bibliógrafo González Barcia fue reconocido como un experto tanto en el ámbito nacional ${ }^{2}$ como en el americanista (Zamora, 1999; Carylon, 2005). Publicó un Ensayo para la historia de la Florida $a^{3}$ anotó muchos textos de historiadores de indias

1 Tuvo el privilegio de participar en la elaboración del Diccionario de Autoridades cuyos seis tomos llegó a ver publicados (1726-1739).

2 Trabajó gran parte de su vida en la anotación a la Bibliotheca Hispana Vetus (1672) y Nova (1696) de Nicolás Antonio. Asimismo reeditó con ampliaciones el Epítome de la Bibliotheca Oriental y Occidental Náutica y Geográfica (1737-1738) de Antonio de León Pinelo.

3 El título completo es Ensayo para la historia de la Florida que contiene los descubrimientos y principales sucesos acaecidos en este gran reino a los españoles, franceses, suecos, dinamarqueses, ingleses y otras naciones entre sí, y con los indios; cuyas costumbres, genios, idolatría gobierno, batallas y astucias se refieren; y los viajes de algunos capitanes y pilotos por el mar del Norte a buscar paso a Oriente, o unión de aquella tierra con Asia, desde el año 1512 que descubrió la Florida Juan Ponce de León hasta el de 1722. Madrid, en la Oficina Real, y a costa de Nicolás Rodríguez Franco, Impresor de Libros, 1723. 
que se editaron póstumamente con el título de Historiadores primitivos de las indias occidentales (1749). Cuando González Barcia muere, una gran parte de su ingente biblioteca, sobre todo manuscritos e impresos, se vendió a la Biblioteca Real en 1744 y otra parte quedó dispersa en bibliotecas particulares.

Su actividad como escritor se sitúa en el arco de tiempo que va de 1690 a 1710 que, según Barrera, corresponde a una etapa de juventud en la que escribió alguna poesía ${ }^{4}$ y teatro, firmando muchas de sus obras con varios seudónimos, entre los que destaca el de D. Ibón, que utilizó en las comedias El apóstol de Grecia, San Andrés (1695); El saco de la gran casa de la Meca (1695); La esclavitud en su patria o Los esclavos de Nápoles (1696) y El gran profeta Eliseo (1697). Bajo el alias de Don García Aznar Vélez aparecieron firmadas en la Parte cuarenta y ocho de comedias las siguientes obras: El sol obediente al hombre (1704); ¿Qué es la ciencia del reinar? y También la piedad con celos. Asimismo, uso el seudónimo Jácome de Cárdenas, Bachiller en Teología por la Universidad de Alcalá de Henares, en la comedia Los peligros de amar (1693). También usó el nombre de Gabriel de Cárdenas (Carylon, 2005: 31-32). Por último, debemos decir que de su pluma salió una farsa burlesca e incompleta (solo se conserva la primera jornada y parte de la segunda) titulada D. Quijote de la Mancha, que aparece enmendada por el propio autor.

\section{EL GRAN PROFETA ELISEO}

Es una comedia de santos con fuertes implicaciones bíblicas, aunque al alborear el siglo xviII ya no hay una distinción entre subgéneros: bíblica, hagiográfica o mariana (Aparicio, 1993: 146). Las comedias de santos llenaron la escena teatral en el siglo XVII y gran parte del siglo XVIII ${ }^{5}$. Aparecen en España hacia 1575 y fueron un importante instrumento de propaganda contrarreformista, pues se aprovechaba del medio más concurrido de la cultura popular (Garasa, 1960; Aragone, 1971; Roux, 1975; Sirera, 1991; Aparicio, 1993; Dassbach, 1997; Velázquez, 2002; Cazés, 2015). La escenificación de la vida de los santos y personajes bíblicos facilitaba al espectador la posibilidad de contemplar un modelo de santidad que resultara edificante a sus intereses morales, a la vez que disfrutaban del espectáculo de la representación. Aparicio (1993) ha calificado este género como una «hagiografía en movimiento», en la que se conjuga a la perfección el santoral cristiano con lo teatral, o

${ }^{4}$ Se ha conservado un romance titulado El patán de Carabanchel, en el que el autor, bajo la apariencia de un rústico, se dirige a la reina por el nacimiento del heredero. Sabemos de otro poema de carácter épico titulado Triunfo glorioso del invicto príncipe mártir San Hermenegildo, rey de Sevilla.

5 El género religioso fue muy popular en el siglo XVIII hasta 1765 , cuando Carlos III prohibió la representación de autos sacramentales y comedias de santos. 
bien, en palabras de Garasa (1960), de santos «sublimados por la magia del teatro». Efectivamente, esta magia dio lugar al rasgo escenográfico que llegó a ser la norma del género porque era la expectativa del público: el uso de tramoyas y artilugios. En consecuencia, la literatura de finales del siglo xVII y primera veintena del siglo siguiente sintió la materia bíblico-hagiográfica de forma más mimética que creadora.

\subsection{Trama}

El gran profeta Eliseo es una comedia que se articula en torno a tres historias; la primera comienza con el relato de Sunamis (2 Reyes 4:14-17) que, desesperada, acude en busca del profeta, pues acaba de fallecer su único hijo. Eliseo la consuela y le insta a tener fe en el Dios verdadero. La música juega aquí un papel profético, pues informa al espectador de lo que a continuación va a suceder, que no es otra cosa que la resurrección del niño sunamita ante el alborozo de su madre (2 Reyes 4:27-37).

La segunda historia afecta al general sirio Naaman, que se lamenta ante los dioses de su mala fortuna y al que Eliseo curó de la lepra haciendo que se sumergiera siete veces en el río Jordán (2 Reyes 5:8-14). A continuación, la judía Jael, le explica al sirio, en un amplio parlamento de 281 versos, quién es Eliseo, los avatares que recorrieron su vida y su ascensión al cielo. Se trata de un discurso que alivia anímicamente a Naaman. En este momento se menciona también, aunque de manera muy superficial y de pasada, el amor que siente Hazael, persona que viene en el séquito del general sirio, por la judía Jael, aunque ella de quien está verdaderamente enamorada es de Jonadab. Esta subtrama amorosa es como una especie de reposo que se le da al público al tiempo que se le prepara para la tercera historia, en la cual Joram, rey de Israel, y el hebreo Jonadab se lamentan por la hambruna y la sequía con las que Dios ha castigado a su pueblo por practicar la idolatría. Joram implora a Eliseo para que Dios les dé clemencia. Eliseo le recomienda al rey que haga oración para lograr la misericordia divina. Gracias a la intervención del profeta, se produce el milagro con la llegada de la lluvia y, por tanto, de la vida. Acaba la comedia con los requiebros amorosos de Jonadab hacia Jael, un amor al que el primero debe renunciar, ya que se impone su rey, su honor y su patria sobre el amor de la dama.

\subsection{Descripción del manuscrito}

El manuscrito que manejo para este estudio se halla en la Biblioteca Nacional de España (Res 172) ${ }^{6}$; al final del mismo aparece la fecha 30/08/1697,

6 El catálogo de BNE dice que el citado manuscrito procede de la biblioteca de Agustín Durán. 
pero no está firmado ni figura el nombre del autor después del título como era lo habitual. Consta de veinticuatro hojas y presenta una letra de finales del siglo Xvir. Barrera (1860) se pregunta si es autógrafa y Paz Meliá (1931: n. 1565) así lo afirma. Según Urzáiz (2002), esta comedia se firmó bajo el seudónimo de García Aznar Vélez, pero lo cierto es que en el documento no figura tal firma. El manuscrito tiene una corta extensión y no está dividido en jornadas, lo cual me hace pensar que se trata de una copia-borrador hecha para una posible representación en la que se detectan varias manos: una, A, que corresponde a la letra de González Barcia y que copia casi todo el manuscrito ${ }^{7}$; otra, B, que interviene escasamente para añadir, suprimir o corregir algunos pasajes del documento; y una tercera mano que escribe en el primer folio debajo del título de la comedia: «creo ser de D. Ibón». Se trata de la misma que añadió «De D. Ibón» entre el título y el listado de personajes. Sin embargo la anotación «sclavos y soldados» [sic], que se halla debajo de la lista de personajes, responde a la letra del dramaturgo. Este juego de plumas era habitual, pues es sabido que los escritores entregaban las obras a los empresarios teatrales, de manera que la mano B que figura en el manuscrito seguramente es la del empresario teatral, el cual adaptó el documento a su gusto para una posible representación. Asimismo hay adiciones que hace la mano $\mathrm{B}$ que responden simplemente a una cuestión de estilo y que en este trabajo siempre señalo en cursiva.

$\begin{array}{cc}\text { Soldado } & \text { Hijo de Gaphat que viene. } \\ & \text { ¡Oh como halagan } \\ & \text { la memoria de Jael } \\ & \text { al oír nombrar su patria! } \\ & \text { Guarda palabra de Dios } \\ & \text { en su corazón. } \\ \text { Jonadab } & \text { si. }\end{array}$

Exactamente lo mismo ocurre con algunas de las modificaciones textuales hechas por González de Barcia en las que simplemente tacha lo que no le gusta y lo cambia, pero sin variar el contenido.

$\begin{array}{ll}\text { Joram } & \begin{array}{l}\text { Đime en su corazón guarda } \\ \text { Guarda palabra de Dios } \\ \text { palabra de Dios. }\end{array} \\ & \text { En su corazón } \\ \text { Yoldí } & \text { ładice el vulgo. } \\ \text { Joram } & \text { Pues baxa } \\ & \text { le buscaremos en el cielo }\end{array}$

7 Es sin duda la letra de Barcia, pues es la misma que figura en sus manuscritos autógrafos. 


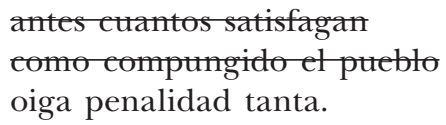

Otras veces es la mano B la que tacha, en este caso un solo verso, y corrige para cambiar el sentido del discurso, como ocurre en la respuesta que le da Eliseo a las súplicas de Joram para que implore a Dios y le conceda el agua.

$\begin{array}{ll}\text { Eliseo } & \text { Vive el Dios Supremo siempre } \\ \text { de exércitos y batallas } \\ \text { en cuya presencia estoy } \\ \text { que si aquí no respetara } \\ \text { el pulso de Josafat, } \\ \text { de Judá, augusto y monarca } \\ \text { hubiera atendido a ti } \\ \text { no te atendiera Joram } \\ \text { y en mi fueran tus palabras } \\ \text { leve vanidad del viento, } \\ \text { del aire lisonja blanda. }\end{array}$

(fol. $18 \mathrm{v})$

Por último vemos la presencia de dos caligrafías, A y B (esta última destacada en negrita), mezcladas para añadir o suprimir palabras.

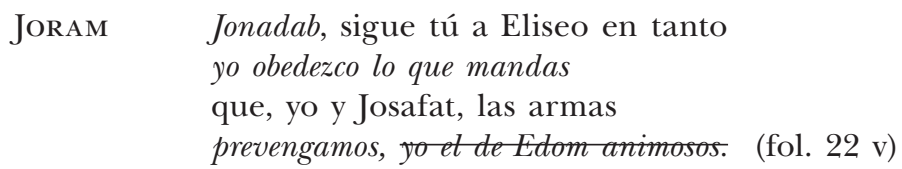

Ahora bien, aunque $\mathrm{El}$ gran profeta Eliseo proyecta un pensamiento claramente defensor de la fe y buenas costumbres morales de la época, lo cierto es que las supresiones, adiciones y modificaciones que tiene el manuscrito van encaminadas, en muchos casos, a evitar problemas con la censura y conseguir la correspondiente licencia de representación; al no contar con un testimonio censor, se hace difícil saber hasta qué punto la comedia pudo ser más o menos reprobada por los calificadores. Pero es un hecho cierto que el teatro religioso estaba muy apoyado por la iglesia porque servía a sus intereses propagandísticos, y al mismo tiempo estaba muy vigilado por ella de los excesos que se pudieran cometer, tanto verbales como gestuales, y que afectaran a las buenas costumbres del tiempo (Urzáiz, 2002: 47-73). Estamos ante un manuscrito corregido y autocensurado, a juzgar por las correcciones textuales que presenta. Así, en el fol. 14 v, la hebrea Jael evoca el amor que siente por Jonadab con unas palabras, correspondientes a la mano A, que encierran cierta ambigüedad, por lo que una segunda mano B añade unos versos, que destaco en cursiva, con el fin de matizar que el ardor amoroso que siente la dama está ligado a la pena y al enfado por el olvido al que la 
tiene sometida Jonadab, más que a cualquier otra circunstancia relacionada con bajas pasiones.

JAEL $\quad$...Ay amor mío que tierno acuerdas mi afecto cuando de tu ardor me irrito, pues ingrato Jonadab aun es su atención olvido.

Asimismo el texto recoge una serie de elementos y comentarios claramente censurables. Se trata de expresiones irrespetuosas con la religión puesta en boca, sobre todo, de las figuras del donaire; así cuando Sunamis implora al cielo para que le devuelva la salud a su hijo, la contestación del gracioso Giezí es irónica e irreverente:

\begin{tabular}{|c|c|c|}
\hline SunAmis & $\begin{array}{l}\text { Hoy de ti } \\
\text { fía Señor mi humildad } \\
\text { que aquella prosperidad } \\
\text { has de volverme. }\end{array}$ & (fol. 2 r) \\
\hline Giezí & Es así yo oraré. & \\
\hline IBERSIA & $\begin{array}{l}\text { Bravo embustero } \\
\text { en mi mente se figura. }\end{array}$ & \\
\hline GiEzí & ¿Cómo? ¿A un santo censura? & \\
\hline IBERSIA & Él es santo. & \\
\hline GiEzí & $\begin{array}{l}\text { Santo y fiero. } \\
\text { Así el azote severo } \\
\text { viera con que suelo darme } \\
\text { con furor hasta dejarme } \\
\text { (no la causa maravilla) } \\
\text { señaladas las costillas }\end{array}$ & \\
\hline & hasta el suelo yo azotarme. & (fol. $2 \mathrm{v})$ \\
\hline Eliseo & $\begin{array}{l}\text { No te advertí que estuvieses } \\
\text { en esa cuadra. }\end{array}$ & \\
\hline Giezí & $\begin{array}{l}\text { Ahí he estado } \\
\text { rezando a voces. }\end{array}$ & (fol. $5 \mathrm{r}$ ) \\
\hline
\end{tabular}

De la misma manera resulta evidente la carga erótica que encierran las palabras del gracioso que revelan una gran procacidad.
Eliseo
Váyase allá afuera ahora.
Giezí
Pues llame necio, si llama, porque elevarme quisiera pero voy me a la cocina que demasido me inclina mi amiga la cocinera.
Da lo que guisa a probar 
a mi estomagazo ayuno, más lo que pruebo a ninguno se lo puedo atravesar.

(fol. 2 v)

Ahora bien, no es tanto el fondo lo que resulta heterodoxo como la forma de representarse, es decir «el propio hecho teatral concebido como espectáculo y no como texto» (Martínez Berbel, 2008: 48).

\subsection{Escenografía y música}

El gran profeta Eliseo mezcla lo religioso con lo profano, lo amoroso con lo doctrinal como ocurría en la comedia hagiográfica barroca. González Barcia no carga las tintas en la trama amorosa, que tiene en la obra un papel más secundario respecto al contenido bíblico-religioso, el cual se articula dentro de una tramoya que potencia lo visual y lo espectacular ${ }^{8}$. La amplia anotación escenográfica que figura en el manuscrito es indicativo de la intención de González Barcia de que la comedia se representara. No importa la vida del santo, de hecho no existe una linealidad en la biografía de Eliseo, pero sí interesa, y mucho, desde un punto de vista técnico, los milagros que Eliseo hizo; esto implica el uso de una escenografía que asegure el espectáculo, algo bastante común en las comedias de santos de finales de siglo xvir y del siglo siguiente (Arellano, 1995; Arróniz, 1977; Ruano, 1994). El profeta Eliseo abre con la siguiente acotación: «Cantan dentro y salen la Sunamitis llorando y Eliseo vestido de profeta, Ibersia y Guijezí de profeta ridículo» (fol. 1 r).

Eliseo queda identificado con la expresión vestido de profeta. El público no necesita más detalles para saber que el personaje en cuestión va vestido con una túnica y porta el báculo de autoridad, tal y como se informa en el Libro Sagrado. Además la vestimenta le proporciona al espectador la condición social del personaje y el tiempo en el que se desarrolla la acción: «Suena dentro la música y sale Naaman, sirio, vestido de púrpura, con barba blanca, muy bizarro y Hazael, sirio, galán, muy bizarro y Jael, dama hebrea y Bercón, sirio ridículo» (fol. 7 r).

En cuanto a la música que suena dentro, aunque no se menciona en el manuscrito con qué instrumentos se tocaba, es seguro que, dado que se trata de un momento de protocolo y solemnidad, fuera la de las chirimías.

Por lo que respecta a las entradas y salidas de los personajes, estas se resuelven escenográficamente mediante el uso de las cortinas, que contribuyen a crear un ambiente dinámico y de continua sorpresa en el espectador: «Entran y ciérrase y salen la Sunamitis e Ibersia» (fol. 3 r).

${ }^{8}$ González Barcia concibió la comedia para representarla ante un público, a juzgar por las varias acotaciones de carácter técnico-escenográfico que contiene el citado texto. 
En otras ocasiones la escenografía contribuye a crear un halo de misterio, como sucede en la escenificación de la resurrección del niño sunamita, que produce una cierta conmoción en el ánimo del público impelido a valorar de manera positiva el coraje y la fe de este insigne profeta:

Ábrese el cenáculo y vese un círculo de rayos que iluminan a Eliseo que está con un niño vestido de hebreo y dos ángeles a los lados; y en habiendo salido los dos al tablado se forman dos semicírculos llevándose cada uno de los ángeles su parte, hasta que se ocultan en las primeras bambalinas del teatro (fol. 5 r).

En el teatro barroco los ángeles aparecían elevados y esto se conseguía con la ayuda del pescante, máquina también usada en otros momentos de la comedia. Asimismo la referencia a los rayos nos permite colegir que la obra estaba pensada para el corral, pues era frecuente que para representarlos se usaran cohetes de subida o bajada o bien algún artificio pirotécnico, pero también:

El rayo se fingiría de una manera bastante primitiva e ingenua. Fabricado de cartón pintado de oro refulgente, se colgaría de un hilo atado de uno de sus extremos. Al finalizar el trueno se le haría descender por su propio peso a través de un filamento con solo ir soltando el cabo del hilo atado (Rodríguez G. de Ceballos, 1989: 41).

En El gran profeta Eliseo también encontramos el monte, que se hacía mediante una rampa que permitía subir y bajar a los actores desde el primer corredor hasta el tablado. Por lo que respecta al fuego, este se producía mojando trozos de tela en aguardiente.

Suenan voces lastimosas y sale en el monte Joram, rey de Israel y Jonadab, hebreo galán y soldados (fol. $16 \mathrm{v}$ ).

En unas llamas aparece una Fénix moviendo apresuradamente las alas y en ella viene un ángel cantando (fol. 19 r).

Es evidente que en $\mathrm{El}$ gran profeta Eliseo la escenografía se va haciendo más complicada, a medida que se acerca el final de la obra, ya que las obras hagiográficas son «comedias de teatro» por su gran vistosidad: poco importa el santo con tal de que se vean sus milagros (Andioc, 1976: 130).

Encúbrase el ángel a la parte de donde luego saldrá el torrente y repite la música mientras Eliseo representa (fol. 19 v).

Por en medio de los paños se figura un arroyo rojo que atraviesa el teatro y se hunde junto a un bastidor (fol. $21 \mathrm{v}$ ).

Se trata de apariencias que se podían colocar en los distintos huecos de la fachada teatral y solían ser lienzos pintados que se fijaban en los bas- 
tidores; se hacía así por la enorme dificultad que entrañaba escenificarlas sobre el tablado. Se descorrían los paños mostrándolas y causando un gran asombro entre el público. González Barcia es prudente en la utilización de decorados; sabe que un uso prolijo de los mismos hará que la comedia pierda credibilidad para el espectador, algo que ya Cervantes criticaba en el Quijote (I, cap. 48):

Pues ¿qué, si venimos a las comedias divinas? ¿Qué de milagros falsos fingen en ellas, qué de cosas apócrifas y mal entendidas, atribuyendo a un santo los milagros de otro!

Por esta razón El gran profeta Eliseo conjuga los valores doctrinales y espectaculares, pero sin vulnerar el espíritu religioso del texto, mientras que la tramoya y los «efectos especiales» cumplen la misión de realzarlo.

Por lo que respecta a la música, esta cumple un objetivo no solo estético, sino también ideológico y dramático. Al ser un manuscrito no dividido en jornadas, las canciones con las que se abre cada una de las tres historias que componen el argumento de la comedia contribuyen a marcar la separación entre actos. Así, al comienzo una acotación nos dice: «Cantan dentro»; se trata de una cancioncilla que interpreta el personaje Música y que dice así:

$\begin{array}{ll}\text { MúsIca } & \text { Entre dolorosas ansias } \\ & \text { ajena a todo alivio } \\ & \text { la infelice Sunamitis } \\ & \text { enciende el aire a suspiros } \\ & \text { repitiendo, jay bien mío } \\ & \text { aún no gozado cuando perdido! } \quad \text { (fol. } 1 \mathrm{r} \text { ) }\end{array}$

De igual manera la historia de Naaman se introduce mediante una intervención de la música que, con carácter profético, anuncia al espectador el drama vivido por este personaje:

Música Fatigado del descanso que ofreció el lecho propicio impacientemente heroico de él se aleja Naaman, sirio. (fol. 7 r)

González Barcia se sirve de la música para manifestar un sentimiento, o bien, para anticipar un suceso (Álvarez Sellers, 1997: 238; Becker, 1989; Stage, 1984: 296) que tiene, la mayoría de las veces, un tinte profético9.

9 Al igual que ocurre en otras insignes obras del teatro barroco como El caballero de Olmedo o El médico de su honra, entre otras muchas. 


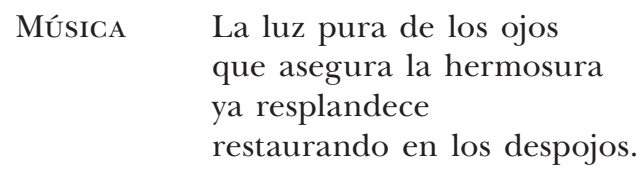

(fol. $4 \mathrm{r}$ )

En este caso concreto la canción anticipa la historia trágica de la muerte del hijo de Sunamis. Es un tipo de cancioncilla de corte polifónico que se solía interpretar a cuatro voces acompañadas de instrumentos de cuerda. El coro la cantaba en escena, puesto que no hay apreciación contraria al respecto.

$\begin{array}{cl}\text { Ángeles } & \text { Brillen los rayos } \\ & \text { del alma que al mundo, } \\ & \text { segunda vez vuelve } \\ & \text { y al sagrado acento, } \\ & \text { al contado débil, } \\ & \text { al caduco polvo, } \\ & \text { animado álcense } \\ \text { tiñendo en ardores } & \text { de la dulce vida, } \\ & \text { funestos horrores } \\ & \text { de la amarga muerte. }\end{array}$

(fol. $3 \mathrm{v})$

Los ángeles en coro solían hacer una combinación tripartita de voces como tiple, tenor, bajo, o bien, alto, tenor y bajo. En esta comedia intervienen para subrayar la grandeza de cada uno de los milagros realizados por Eliseo. Se trata de exaltar el milagro de la resurrección del hijo de Sunamis:

$\begin{aligned} \text { ÁNGELES } & \text { Los alientos divididos } \\ & \text { a tormentos en fragmentos } \\ & \text { se recuperen } \\ & \text { y se gocen los sentidos, } \\ & \text { pues hoy proseguir } \\ & \text { su obra adquieren. }\end{aligned}$

(fol. $4 \mathrm{v})$

Música Ay qué niños tan hermosos le asisten [a Elías]. Haced se quede uno conmigo siquiera.

En la tercera de las historias los Ángeles, cantando, explican al espectador las razones por las que Dios ha castigado al pueblo de Joram:

$\begin{aligned} \text { ÁNGELES } & \text { Penetrando de los cielos } \\ & \text { tus oraciones hallan } \\ & \text { en la mente divina } \\ & \text { aceptación humana, } \\ & \text { sin vientos y sin llamas } \\ & \text { verás de esa campaña } \\ & \text { la árida superficie }\end{aligned}$




$$
\begin{aligned}
& \text { en cristal sepultada. } \\
& \text { Las huestes de Moab } \\
& \text { serán desbaratadas, } \\
& \text { su ciudad destruida, } \\
& \text { su región asolada, } \\
& \text { los árboles y fuentes } \\
& \text { al rigor y a la saña } \\
& \text { de Israel y Judá } \\
& \text { serán cenizas vagas. }
\end{aligned}
$$

El juego teatral de la polifonía coral buscaba no solo un efecto visual, con la disposición externa de los coros en el escenario, sino también contribuir con el sonido a convertir la vida cotidiana en un espectáculo teatral. Se pretende potenciar la acción dramática, pues lo que entra por los ojos y por los oídos llega hasta el corazón. Otras veces los coros y los músicos entran a escena convenientemente provistos de sus instrumentos y de sus voces:

$\begin{array}{ll}\text { Eliseo } & \text { Traed algunos instrumentos. } \\ & \text { Músicos, con que alternadas } \\ & \text { sus voces y las mías sean } \\ & \text { en suave consonancia } \\ & \text { llaves que el azul viril } \\ & \text { imperiosamente abran. }\end{array}$

(fol. $18 \mathrm{v})$

Por tanto, la música en esta comedia de González Barcia, como en la mayor parte del teatro hagiográfico del Barroco, contribuye a articular el discurso escénico y a «reducir en la medida de lo posible el distanciamiento entre espectador y representación»(Caballero, 2003: 682).

\subsection{Dramatis Personae}

\subsubsection{Eliseo $^{10}$}

Teatralmente Eliseo es el personaje sobre el que recae todo el peso de la acción dramática. Decía Menéndez Pelayo que no se puede hacer una comedia de santos «con un Doctor de la Iglesia que tradujo las Sagradas Escrituras,

10 Es un personaje que tiene un origen bíblico. Nació y habitó en Abel-Mehola, en Israel entre 850 y 800 a. C. En el Libro de los Reyes (2 Re 2: 1-17) se nos dice que era el discípulo privilegiado de Elías que, a la muerte de este, continuó la labor profética de su maestro durante el reinado de los reyes Joram, Jehú, Joacaz y Joás. Dentro del cristianismo, Eliseo es considerado un importante precursor de Jesús, pues era un hombre bondadoso y caritativo que tuvo que lidiar con la idolatría. En cuanto a la iconografía, hay que decir que la figura de este profeta ha suscitado el interés de artistas, sobre todo de pintores, gracias al conocimiento de lo reflejado en el Libro Sagrado. Varias son las pinturas sobre el profeta: Eliseo multiplica los panes de Tintoretto (1577-78, Scuola di San Rocco, Venecia), El profeta Eliseo de Giorgio Vasari (1566, Galleria degli Uffizi, Florencia), Eliseo rehusando los regalos de Naamán de Pieter Grebber (1637, Museo Frans Hals, Haarlem), Eliseo resucita al hijo de la sunamita, en 
que disputó con todos los herejes de su tiempo, que fue elocuente y sapientísimo» (apud Teulade, 2008: 85), es decir, un santo lineal, sin ondulaciones en su conducta, que no despierta tanto interés para el espectador como otros que experimentan una conversión de pecadores a santos. Es cierto que Eliseo es un manojo de perfecciones; incluso desde la nómina de personajes se matiza que es un viejo venerable, pero no por ello resulta un personaje lineal, sino todo lo contrario, pues es vehemente y apasionado en la defensa de su fe frente a la idolatría imperante en su época. Los milagros que realiza son instrumentos que Dios le otorga para instar a las gentes paganas a la adopción de la verdadera fe en Yahvé. Así en el primero de los milagros, la resurrección del niño sunamita, el profeta alza los ojos a Dios implorando misericordia para con los pecadores:

$$
\begin{aligned}
& \text { Eliseo } \quad \text { Jericó sane las aguas fiel } \\
& \text { arrojando en lo amargo dura sal, } \\
& \text { en infames rapaces fue fatal } \\
& \text { mi maldición encima de Berbel } \\
& \text { de la opresión del acreedor cruel, } \\
& \text { los hijos redimí del inmortal } \\
& \text { Abdías, siervo tuyo siempre igual, } \\
& \text { que a su viuda intento quitar, infiel, } \\
& \text { de esta mujer el ruego has de advertir, } \\
& \text { borrando en ella el trágico dolor, } \\
& \text { que tanto pudo su ánimo afligir. } \\
& \text { Por ti le prometí yo el sucesor } \\
& \text { que ha fallecido vuelva ya a vivir, } \\
& \text { si es tuya mi palabra, Gran Señor. (fol. } 3 \mathrm{r} \text { ) }
\end{aligned}
$$

Eliseo, como no podía ser de otra forma, representa el triunfo del bien que se hace visible para el espectador mediante la realización de milagros, que son vistos por el espectador como un hecho sobrenatural que le reconforta el espíritu y, por supuesto, acentúan la espectacularidad de la comedia.

\subsubsection{Joram ${ }^{11}$, rey de Israel, y Jonadab ${ }^{12}$, hebreo}

Desde el punto de vista dramático, Joram y Jonadab son dos personajes necesarios y complementarios para que se produzca el milagro de Eliseo en

Horas de Anne de Montmorency (1546, Museo Condé, Chantilly), icono del profeta Eliseo (1654, Iglesia de San Juan, Korovniki), etc.

${ }^{11}$ Joram era hijo de Ahab y de la temida Jezabel. Su historia está recogida en el Segundo libro de los Reyes (2 Re 3: 1 a 27). Joram desobedeció a Dios, pues destruyó el lugar que su padre había preparado para adorar a Baal. Sin embargo, Joram no pudo renunciar del todo al politeísmo.

12 Jonadab es una figura de la que apenas habla la Escritura; aparece en 2 Samuel 13. Era hijo de Shimeah, hermano de David. El Libro Segundo de Samuel 13 describe cómo 
el que ellos están implicados, pues ambos simbolizan el sufrimiento extremo, representado por la hambruna y la sequía.

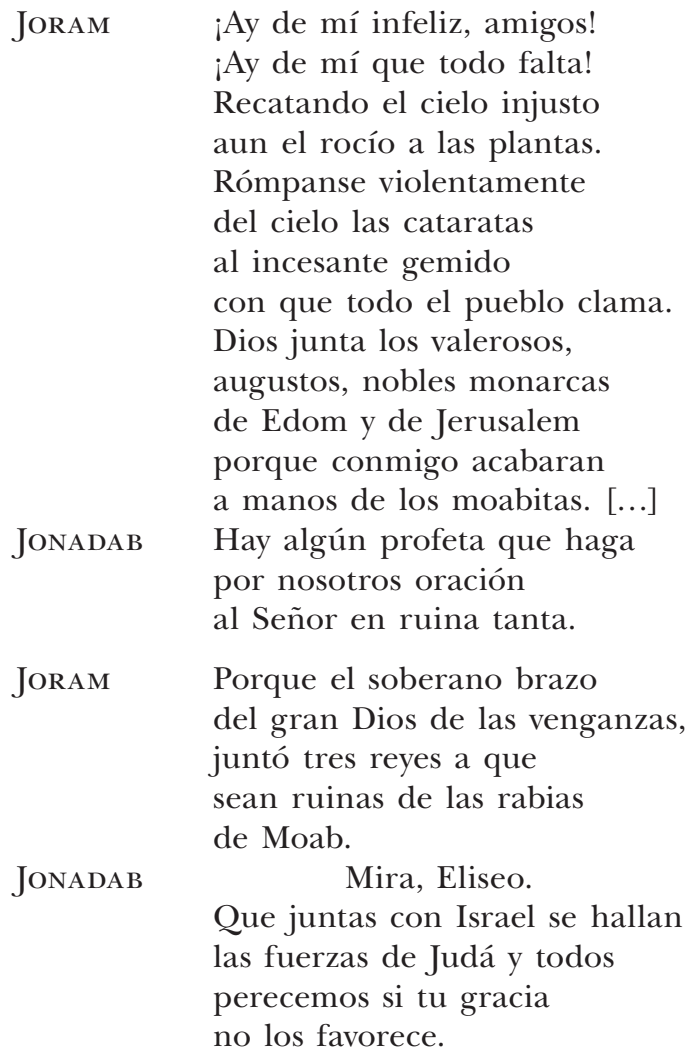

(fol. $17 \mathrm{r}$ )

(fol. $18 \mathrm{r}$ )

Jonadab también aparece en la comedia como galán, enamorado de la judía Jael y de quien también está enamorado el sirio Hazael. Jonadab, como todo galán que se precie, siente el amor hacia su dama teñido también de celos al creer que ella ama a otro. Así le dice a su dama.

Jonadab En dando muerte a ese aleve, yo te juro por las altas esferas que no volveré a mirarte jamás.

(fol. $24 \mathrm{v})$

Finalmente renunciará al amor de Jael anteponiendo su deber para con su rey, su honor y su patria.

Jonadab contribuyó a que Amnón violase a Tamar, pues Jonadab le aconsejó que fingiera estar enfermo y luego le pidió a David que le enviara a Tamar para que le preparara algo de comida. Amnón siguió el consejo de Jonadab y se produjo el estupro. 
Quién pudiera averiguar sus celos, pero me llaman contra mi amor, mi valor, mi rey, mi honor y mi patria, y por acudir a tanto, es preciso le haga falta.

(fol. $24 \mathrm{v})$

\subsubsection{Hazael $^{13}$}

En la comedia Hazael figura como galán y, en ningún momento, se hace referencia a su papel como hombre de estado. El sirio cae rendido ante los encantos de Jael y solo vive por y para conseguir el amor de la dama.

\begin{tabular}{lll} 
Hazael & $\begin{array}{l}\text { En sus luces abrasado } \\
\text { muero todo lo que vivo. }\end{array}$ & \\
& \multicolumn{1}{c}{$[$ fol. $8 \mathrm{r}$ ) } \\
& ¿De dónde gallarda hebrea & \\
& en vano a esforzarme aspiro & \\
porque están bebiendo incendios & \\
en su beldad mis sentidos & \\
esos portentos supiste? & (fol. $14 \mathrm{v})$
\end{tabular}

$\mathrm{Su}$ papel en la obra es secundario, pues en realidad es el que acompaña a Naaman a ver al profeta Elías para que lo cure de la lepra. Su presencia contribuye a dar sentido a la trama amorosa, de carácter profano, tan habitual en este tipo de comedias.

\subsubsection{Naaman ${ }^{14}$, el sirio}

La presencia en escena de este personaje viene anunciada en una acotación en la que se informa de como Naaman sale «vestido de púrpura con barba blanca, muy bizarro». Ya la música pone en antecedentes al espectador del enorme sufrimiento que supone esta enfermedad para quien la padece y cómo Naaman, postrado en la cama, se levanta para encontrarse con Eliseo. Sin duda, se trata de subrayar la fuerza de la fe.

13 Rey de Aram-Damasco (842-805 a.C.); antes de asumir el cargo fue un alto oficial de Ben-Hadad II, a quien sucedió en el trono. En Damasco preguntó al profeta Eliseo sobre la enfermedad del entonces rey. Eliseo profetizó la muerte del monarca y la proclamación de Hazael como rey; Elías le dijo que sería muy cruel con Israel. Hazael regresó al palacio, y, de manera hipócrita, le dijo a su rey: «el profeta ha dicho que ciertamente mejorarás».

${ }_{14}$ Su nombre aparece también en el Evangelio de Lucas 4: 27. Era General de los ejércitos del rey Ben-Adad II en tiempos de Joram, rey de Israel. Su historia aparece recogida en el segundo Libro de los Reyes. Padecía de lepra y una joven esclava hebrea al servicio de su esposa le habló de un profeta de Samaria que podía curarlo. Eliseo le dice que para sanar deberá lavarse siete veces en el río Jordán. 


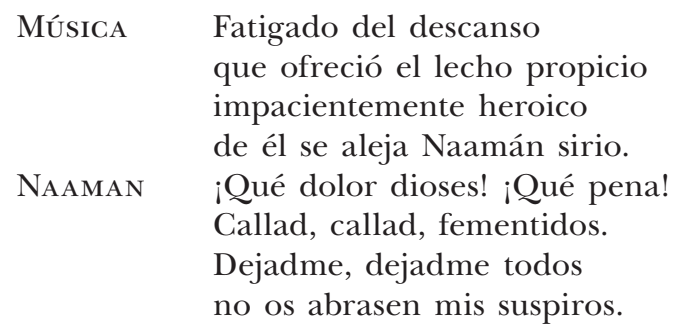

La curación física de Naaman supone también la curación de su alma:

Partir resuelvo al propicio suelo de Samaria. Al gran

Benadab esclarecido, monarca de Siria voy al referir los prodigios de este hombre para que escriba al rey de Israel que si no haga que me dé salud, o entre las ansias que vivo, sepultándome mis iras, sea trofeo del abismo. (fol. $7 \mathrm{r}$ ) 


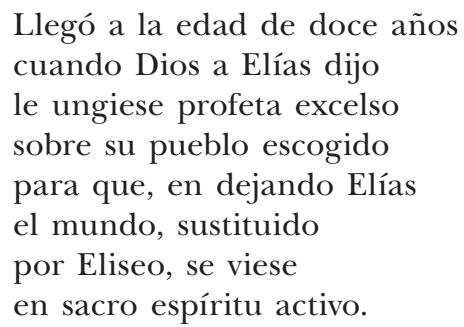

(fol. 9 r)

Además, Jael representa el tipo de dama de la Comedia Nueva implicada en la trama amorosa; está enamorada de Jonadab pero no es plenamente correspondida y, por tanto, sufre el desamor y los celos; a su vez, es amada por Hazael, a quien no corresponde.

JAEL ¿Lo has visto pues?
Quién tan torpes, tan villanas
intenciones tiene, nunca
volverá a verme la cara.
JonADAB dando muerte a ese aleve,
Eo te juro por las altas
esferas de no volver
a mirarte jamás.

(fol. $24 \mathrm{v})$

Pero la trama amorosa de esta comedia es endeble y su fin es rebajar la tensión dramática en el espectador de la parte doctrinal, que constituye la raíz esencial del argumento.

\subsubsection{Figuras del donaire}

De los tres personajes que intervienen en este apartado, Giezí, Ibersia, ambos judíos, y Dercón, gracioso sirio, solo Giezí está documentado en el Antiguo Testamento como criado del profeta Eliseo. Dios le castigó, por avaro y mentiroso, a padecer la lepra de la que fue curado el general sirio Naaman (2 Re 5: 27).

Dercón e Ibersia, son personajes comparsa que caminan al abrigo de Giezí, que es el que lleva el peso de la acción cómica. Su conducta otorga cercanía respecto a la realidad, más solemne y religiosa, que representa su amo, Eliseo, de quien se constituye en digno contrapunto.

$\begin{array}{ll}\text { Ibersia } & \text { ¿Por qué Giezí? } \\ \text { Giezí } & \text { Porque su ama llora } \\ & \text { Y siempre de la señora } \\ & \text { mona la criada fue. } \\ & \text { Pero, dime, ¿dónde está } \\ & \text { aquella amiga de tu ama } \\ & \text { que era tan bizarra dama? }\end{array}$


¿Cómo continúa?

¿Vendrá hoy a casa?

(fols. $1 \mathrm{v}-2 \mathrm{r}$ )

El papel de estas figuras consiste en dar juego dramático en el contexto festivo de la representación de carácter religioso; así vemos a Dercón, cómo tiene una intervención cómica cuando, al oír el largo discurso que pronuncia Jael sobre el profeta Eliseo, rompe la solemnidad del mismo:

¿Qué bien ha hecho de justicia!

Está mereciendo el vítor.

(fol. $14 \mathrm{r}-\mathrm{v}$ )

González Barcia configura las figuras del donaire con un acierto tal que el espectador, o bien, el lector de la comedia, tiene la sensación de que estos personajes nos acercan a las muchas y breves causas que la vida tiene para reír y nos alejan de las pocas y largas que tiene de llorar.

\section{Conclusiones}

El gran profeta Eliseo es una comedia inédita que espero en breve pueda ver la luz. Se trata probablemente de un borrador, ya que tiene una atípica extensión, pero, aun así, encierra unos logros teatrales nada insignificantes. La obra responde a los usos, modas y costumbres teatrales de su tiempo, donde el gusto por lo maravilloso y espectacular era la baza que aprovechaban los dramaturgos para hacer comedias que tuvieran una escenografía llamativa y atractiva para el público. Aunque no se tienen datos acerca de su representación, no cabe duda de que El gran profeta Eliseo fue una pieza concebida para ser llevada a la escena, pues las varias acotaciones del texto van encaminadas a lograr una comunicación con los medios y recursos del espectáculo. Es una pieza estimable dentro del corpus teatral de González Barcia, un dramaturgo muy olvidado que es necesario recuperar; su papel en la escena española de finales del siglo XviI, junto con la de otros contemporáneos, resultó interesante, pues todos ellos tuvieron el mérito de intentar conservar los esquemas teatrales del barroco en el siglo xviII, una centuria que como se sabe ya estaba más interesada en otras nuevas fórmulas teatrales.

\section{Bibliografía}

Aguilar Piñal, F. (1981-2002): Bibliografía de autores españoles del siglo XVIII. Madrid, CSIC.

Aparisi, L.M. (2013): Gallegos en la Real Academia Española. Madrid, Asoc. Cultural da Vieira.

Álvarez Baena, J.A. (1789-1791): Hijos de Madrid. I. Madrid, Benito Cano. 
Álvarez Sellers, M.R. (1997): «La música como emblema de lo trágico: las canciones en la tragedia del Siglo Oro». En Virgili, M.A. y Vega, G. (eds.): Música y literatura en la Península Ibérica (1600-1750). Valladolid, Universidad de Valladolid, págs. 221-239.

Andioc, R. (1976): Teatro y sociedad en el Madrid del siglo XVIII. Madrid, Castalia.

ANDrÉs, G. de (1987): «La biblioteca manuscrita del americanista Andrés González de Barcia (†1743), del Consejo y Cámara de Castilla». Revista de Indias, 47, págs. 811-831.

Aparicio, J. (1993): «A propósito de la comedia hagiográfica barroca». En García, M. (ed.): Estado actual de los estudios sobre el Siglo de Oro. Salamanca, Universidad de Salamanca, vol. 1, págs. 141-153.

Aragone, E. (1971): Studio sulle «Comedias de santos» di Lope de Vega. Messina-Firenze, D'Anna.

Arellano, I. (1995): «Escenario y puesta en escena en la comedia de santos: el caso de Tirso de Molina». Cuadernos de teatro clásico, 8, págs. 157-180.

Arróniz, O. (1977): Teatros y escenarios del Siglo de Oro. Madrid, Gredos.

Barrera, C. de la (1860): Catálogo bibliográfico y biográfico del teatro antiguo español, desde sus orígenes hasta mediados del siglo XVIII. Madrid, Rivadeneyra.

Becker, D. (1989): «Música de instrumentos, bailes y danzas en el teatro español del Siglo de Oro». Cuadernos de Teatro Clásico, 3, págs. 171-190.

Caballero, C. (2003): «La música en el teatro clásico». En Huerta Calvo, J. (ed.): Historia del teatro español. I. De la Edad Media a los Siglos de Oro. Madrid, Gredos, págs. 38-60.

Carylon, J.E. (2005): Andrés González de Barcia and the Creation of the Colonial Spanish American Library. Toronto, University of Toronto Press.

CAzés G.D. (2015): «La comedia de santos y el teatro en el Siglo de Oro». Atalanta, 3.2, págs. 37-70.

Dassbasch, E. (1997): La comedia hagiográfica del Siglo de Oro español: Lope de Vega, Tirso de Molina y Calderón de la Barca. New York, Peter Lang.

Fayard, J. (1982): Los miembros del Consejo de Castilla (1621-1746). Madrid, Siglo XXI.

Garasa, D.L. (1960): Santos en escena: estudio sobre el teatro hagiográfico de Lope de Vega. Bahía Blanca, Cuadernos del Sur.

Madroñal, A. (2010): «La comedia inédita Don Quijote de la Mancha, de Andrés González Barcia». Anales Cervantinos, 42, págs. 305-352.

Martínez Berbel, J.A. (2008): «La comedia de santos entre la heterodoxia y la licitud». En Pedraza, F.B. y García, A. (eds.): La comedia de santos. Almagro, Universidad de Castilla-La Mancha, págs. 21-39.

Paz Meliá, A. (1931): Catálogo de las piezas de teatro que se conservan en el Departamento de Manuscritos de la Biblioteca Nacional, vol. I. 2.. ed. Madrid, Biblioteca Nacional.

Rodríguez G. de Ceballos, A. (1989): «Escenografía y tramoya en el teatro español del siglo Xviı». En Egido, A. (ed.): La escenografía del Barroco. Salamanca, Universidad de Salamanca, págs. 33-60. 
Ruano, J.M. (1994): Los teatros comerciales del siglo XVII y la escenificación de la comedia. Madrid, Castalia.

Roux, L. (1975): Du logos à la scène: éthique et esthétique. La dramaturgie de la comédie de Saints dans l'Espagne du siècle d'Or (1580-1635). Tesis Doctoral. Université de Lille.

SÁnchez MARiAna, M. (1993): Bibliófilos españoles desde sus orígenes hasta los albores del siglo XX. Madrid, Biblioteca Nacional.

Sirera, J.L. (1991): «Los santos en sus comedias: hacia una tipología de los protagonistas del teatro hagiográfico». En Diago, M. y Ferrer, T. (eds.): Comedias y comediantes: estudios sobre el teatro clásico español. Valencia, Universidad de Valencia, págs. 55-76.

Stage, J. (1984): «La música en los corrales». En Diago, M. y Ferrer, T. (eds.): El corral de comedias. Escenarios, sociedad, actores. Madrid, Teatro Español, págs. 296-297.

Teulade, A. (2008): «Santidad y teatralidad: el santo como paradoja estética». En Pedraza, F.B. y García, A. (eds.): La comedia de santos. Almagro, Universidad de Castilla-La Mancha, págs. 85-99.

Urzáız, H. (2002): Catálogo de autores teatrales del siglo XVII. Madrid, Fundación Universitaria Española.

VelázQuez, I. (2002): Hagiografía y culto a los santos en la España visigoda: aproximación a sus manifestaciones literarias. Mérida, Museo Nacional del Arte Romano.

Zamora, A. (1999): Historia de la Real Academia Española. Madrid, Espasa-Calpe. 